\title{
Oat bran in cardiovascular risk control in mental disorder
}

\author{
Farelo de aveia no controle de risco cardiovascular em transtorno mental \\ Salvado de avena en el control del riesgo cardiovascular en el trastorno mental
}

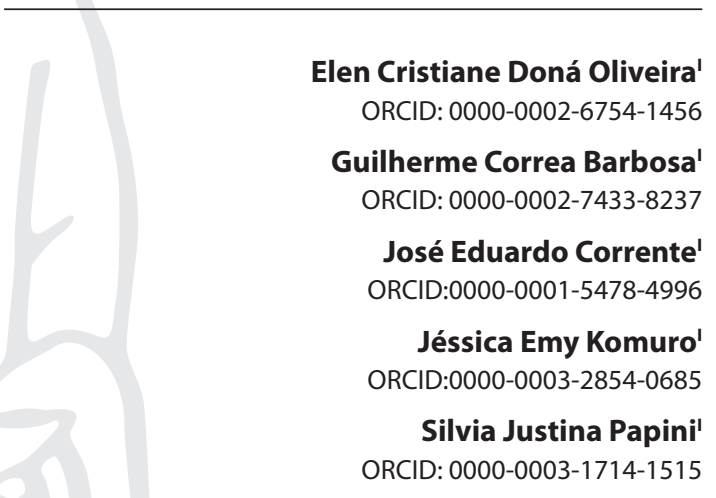

'Universidade Estadual Paulista Júlio de Mesquita Filho. Botucatu, São Paulo, Brazil.

How to cite this article:

Oliveira ECD, Barbosa GC, Corrente JE, Komuro JE, Papini SJ. Oat bran in cardiovascular risk control in mental disorder. Rev Bras Enferm. 2020;73(Suppl 1):e20190277. doi: http://dx.doi.org/10.1590/0034-7167-2019-0277

\section{Corresponding author:} Silvia Justina Papini E-mail: silvia.papini@unesp.br

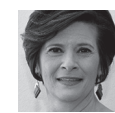

EDITOR IN CHIEF: Antonio José de Almeida Filho ASSOCIATE EDITOR: Andrea Bernardes

Submission: 03-26-2019

Approval: 12-05-2019

\begin{abstract}
Objective: To evaluate the effect of oat bran supplementation on cardiovascular risk components of patients with mental disorders. Method: A before-and-after study, no contro group. Cardiovascular risk indicators were assessed at baseline (M0), 90 (M1), 180 days (M2) and 180 days after supplementation (M3). Results: Of the 45 patients admitted to a psychiatric institution using antipsychotics, more than two thirds had high cardiovascular risk assessed by abdominal obesity. Forty-six point seven percent were overweight and $31.1 \%$ metabolic syndrome. Oat bran was effective in reducing serum cholesterol (M0-M1), HDL-cholesterol (M1-M2), triglycerides (M1-M2), (M2-M3) and (M1-M3). In M3, there was a statistical difference for all indicators evaluated. Conclusion: Oat bran supplementation was effective in improving triglyceride, total cholesterol and HDL-cholesterol levels, suggesting that it is a therapeutic option for cardiovascular risk control in patients with psychiatric disorders.
\end{abstract}

Descriptors: Schizophrenia; Metabolic Syndrome; Dietary Fiber; Oats; Chronic Diseases.

\section{RESUMO}

Objetivo: Avaliar o efeito da suplementação de farelo de aveia sobre os componentes de risco cardiovascular de pacientes com transtornos mentais. Método: Estudo antes e depois, sem grupo controle. Foram avaliados os indicadores de risco cardiovascular no início (M0), 90 (M1), 180 dias (M2) e 180 dias após a suplementação (M3). Resultados: Dos 45 pacientes internados em uma instituição psiquiátrica em uso de antipsicóticos, mais de dois terços apresentaram risco cardiovascular elevado avaliado pela obesidade abdominal. $46,7 \%$ apresentou excesso de peso e 31,1\% síndrome metabólica. O farelo de aveia mostrouse eficaz na redução do colesterol sérico (M0-M1), HDL-colesterol (M1-M2), triglicerídeos (M1-M2), (M2-M3) e (M1-M3). Em M3 houve diferença estatística para todos os indicadores avaliados. Conclusão: A suplementação do farelo de aveia foi eficaz para melhora dos níveis de triglicérides, colesterol total e HDL-colesterol, sugerindo ser uma opção terapêutica para controle dos riscos cardiovasculares de pacientes com transtornos psiquiátricos.

Descritores: Esquizofrenia; Síndrome Metabólica; Fibra Alimentar; Aveia; Doenças Crônicas.

\section{RESUMEN}

Objetivo: Evaluar el efecto de la suplementación con salvado de avena en los componentes de riesgo cardiovascular de pacientes con trastornos mentales. Método: Un estudio antes y después, sin grupo control. Los indicadores de riesgo cardiovascular se evaluaron al inicio del estudio (M0), 90 (M1), 180 días (M2) y 180 días después de la suplementación (M3). Resultados: De los 45 pacientes ingresados en una institución psiquiátrica que usan antipsicóticos, más de dos tercios tenían un alto riesgo cardiovascular evaluado por obesidad abdominal. $46.7 \%$ tenían sobrepeso y $31.1 \%$ síndrome metabólico. El salvado de avena fue eficaz para reducir el colesterol sérico (M0-M1), el colesterol HDL (M1-M2), los triglicéridos (M1-M2), (M2-M3) y (M1-M3). En M3 hubo una diferencia estadística para todos los indicadores evaluados. Conclusión: La suplementación con salvado de avena fue efectiva para mejorarlos niveles de triglicéridos, colesterol total y colesterol HDL, lo que sugiere que es una opción terapéutica para el control del riesgo cardiovascular en pacientes con trastornos psiquiátricos.

Descriptores: Esquizofrenia; Síndrome Metabólico; Fibra Alimentaria; Avena; Enfermedades 


\section{INTRODUCTION}

Schizophrenia is a neuropsychiatric disorder that causes work disability, and most patients are unable to achieve full functional recovery, causing burden to the caregiver ${ }^{(1)}$. Patients with this mental illness, considered chronic, develop visual and auditory hallucinations, persecutory delirium, constant dreams and nightmares, aggressiveness, among others. With the advancement of research and development of new drugs for the treatment of mental disorders, second generation antipsychotics (SGA) have emerged, with numerous advantages over previous ones, and less extrapyramidal side effects ${ }^{(1-3)}$. In contrast, chronic use of this therapy is associated with the onset of metabolic changes that significantly increase the risk of death from cardiovascular disease (CVD), today the leading cause of death in individuals with schizophrenia(4).

These individuals have a higher risk of metabolic disorders when compared to the general population, mainly due to risk factors for CVD, such as abdominal obesity, assessed by waist circumference by height ratio ${ }^{(5)}$, dyslipidemia, hypertension and type 2 diabetes mellitus $s^{(4,6-8)}$. The explanations for these changes are diverse, arising from the disease itself - increased stress ${ }^{(9)}$, inflammatory response ${ }^{(9)}$, drug side effect ${ }^{(4)}$ and also factors linked to genetic components ${ }^{(9)}$ and lifestyle, as a sedentary lifestyle and inadequate food consumption ${ }^{(8)}$.

Since for these individuals the use of SGA cannot be replaced, control actions for CVD precursor comorbidities, such as nonpharmacological treatments, should be implemented. Faulkerner et al, $2003^{(10)}$, in a systematic review with patients with schizophrenia, showed that short-term weight loss seems to be possible through changes in diet and behavior. Therefore, it should be recommended, but needs support from the health service to better adhere to such changes.

A non-pharmacological therapeutic option for prevention and control of metabolic disorders is increased dietary fiber intake. Increased consumption of whole grains and fiber is associated with decreased insulin resistance index ${ }^{(11-13)}$. The American Dietetic Association ${ }^{(14)}$ recommends a daily intake of 20-35 g of dietary fiber or 10 to $14 \mathrm{~g}$ of fiber/1,000 kcal. The Brazilian Guideline for Dyslipidemia and Atherosclerosis Prevention, $2017^{(15)}$, recommends the consumption of $25 \mathrm{~g}$ of fiber, with $6 \mathrm{~g}$ of soluble fiber as ideal in daily diet.

The daily consumption of dietary fiber, especially beta-glucan, soluble fiber present in oat and barley bran, is directly related to several health benefits, including weight loss and control of changes in cardiovascular risk factors ${ }^{(16)}$. Beta-glucan is well known for its postprandial glucose and insulin-lowering effects ${ }^{(11-12)}$, which contributes to the prevention and treatment of type 2 diabetes ${ }^{(11,13)}$. A recent study ${ }^{(17)}$ demonstrated a significant doseresponse effect of oat bran beta-glucan, even with low amounts, on postprandial glycemic response.

In addition to the effects on blood glucose, by reducing the absorption of sugars, dietary fibers make it difficult to absorb fat. They help lower cholesterol levels, triglycerides, proven by studies that found that high-fiber diets decrease the risk of CVD ${ }^{(16,18-19)}$. Daily consumption of 3 to $6 \mathrm{~g}$ of beta-glucan contributes to a $5 \%$ reduction in $\mathrm{HDL}$-cholesterol levels and a decrease in glycemic indexes. Proper fiber intake in the form of oat bran resulted in decreased total cholesterol and LDL-cholesterol concentrations ${ }^{(16,18-19)}$.
Considering the difficulties of individuals with mental disorders in taking care of their health and diet and the low cost, ease of use and lack of studies in this area, it can be considered that oat bran supplementation may be a preventive therapeutic alternative. or treatment of metabolic disorders for patients on chronic antipsychotic use.

\section{OBJECTIVE}

To evaluate the effect of oat bran supplementation on cardiovascular risk components of patients with mental disorders.

\section{METHODS}

\section{Ethical aspects}

The study period was and was approved by the Research Ethics Committee of Faculdade de Medicina de Botucatu (UNESP).

\section{Study desing, location and period}

This is a before-and-after quantitative study, without control group, post intervention, in a psychiatric institution in the countryside of São Paulo from November 2015 to November 2016.

\section{Population and inclusion criteria}

The study included 45 patients residing in the institution for more than five years, in clinical conditions, agreed to participate in the study and signed the Informed Consent Form.

\section{Study protocol}

Anthropometric measurements, metabolic alterations and cardiovascular risk factors were evaluated. In the anthropometric evaluation, weight and height were measured, and the nutritional diagnosis was determined according to body mass index (BMI) values, calculated from the body weight ratio by squared height, using the proposed values as reference. World Health Organization $(\mathrm{WHO})^{(20)}, 1998$, for adults, and the Nutrition Screening Initiative $(\mathrm{NSI})^{(21)}, 1992$, for individuals over 60 years. Waist circumference (WC) was measured to assess metabolic risk and to calculate waist/height ratio (WHtR) to determine abdominal obesity ${ }^{(22)}$. A cut-off point of 0.50 for both sexes was considered to assess the risk of cardiovascular events. Blood tests were performed to assess fasting plasma glucose, triglycerides, total cholesterol, and HDL-cholesterol levels ${ }^{(23)}$.

Most subjects used neuroleptic, anticonvulsant, mood stabilizing, antihistamine and antihypertensive medications as routine medications. Information on the medications used and the dosage were obtained from the medical records.

After the initial evaluation of anthropometric and biochemical indicators, all individuals underwent an intervention protocol with oat bran supplementation for 180 days. It was measured at baseline (M0) after ninety (M1) and one hundred and eighty days (M2) and one hundred and eighty days after the last oat bran supplementation (M3), the evolution of anthropometric indicators and biochemical tests (four moments). All participants received the usual diet offered by the hospital plus $20 \mathrm{~g}$ of oat bran added to milk for breakfast. 


\section{Analysis of results and statistics}

For the analysis of the results, initially a descriptive analysis of the anthropometric and biochemical variables was performed, with calculation of mean and standard deviation in the four moments. The comparison between the moments to evaluate the effect of fiber consumption was made using repeated measures ANOVA followed by Tukey's multiple comparison test for variables with symmetrical distribution. In case of asymmetry, the same model was used by adjusting a gamma distribution followed by the Wald multiple comparison test. In all tests the significance level of $5 \%$ or corresponding $p$ value was used. All analyzes were performed by the SAS for Windows program.

\section{RESULTS}

Forty-five patients were evaluated. Of these, $62.2 \%$ (28) were male, with a mean age of $55.5 \pm 13.2$ years, minimum of 25 and maximum of 81 years, and $64.4 \%$ (30). they were under 60 years old. In their totality, they were patients dependent on assistance in activities of daily living, especially self-care, due to mental illness, and had good institutional coexistence.

Table 1 presents the results of the nutritional indicators of the patients evaluated at baseline (M0).

When assessing cardiovascular risk by changes in WC measurement, $75.6 \%$ (34) of the study group were at high risk for cardiovascular events. Of women, $94.0 \%$ (16) had increased WC, and of men, $50.0 \%$ (14). Considering the WHtR, this condition worsens, since $82.2 \%$ (37) presented values above the cutoff value (0.5).

Figure 1 shows the classification of nutritional status using $\mathrm{BMI}$ values for each age group at baseline (M0).

Table 1 - Descriptive measures for anthropometric indicators evaluated at the baseline (M0) of individuals with mental disorder, Botucatu, São Paulo, Brazil, 2016

\begin{tabular}{ccc}
\hline Anthropometry & Mean & Standard Deviation \\
\hline Weight $(\mathrm{kg})$ & 71.2 & 14.2 \\
Height $(\mathrm{cm})$ & 1.62 & 0.09 \\
BMI (kg/m2) & 27.3 & 5.9 \\
WC (cm) & 98.5 & 15.6 \\
WHR & 0.61 & 0.11
\end{tabular}

Note: M0: baseline, $\mathrm{kg}$ : kilogram, $\mathrm{cm}$ : centimeters, $\mathrm{kg} / \mathrm{m}^{2}$ : kilogram per square meter, BMl: Body Mass Index, WC: Waist Circumference, WHtR: Waist-to-Height Ratio.

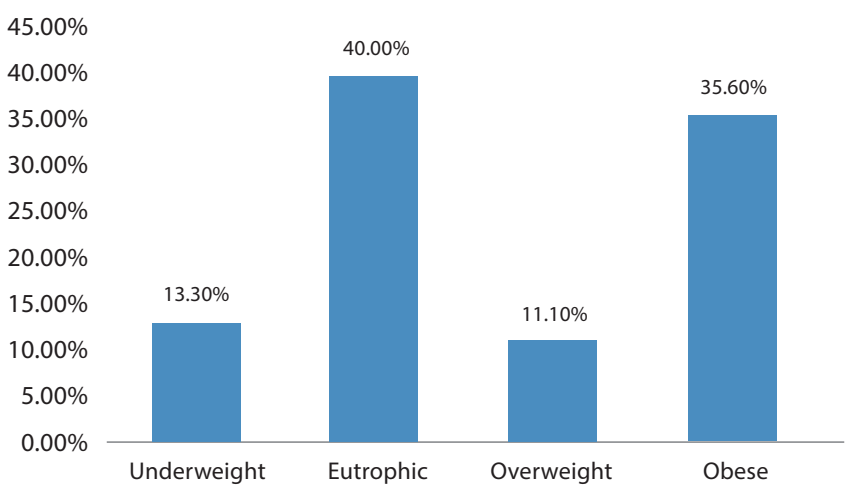

Figure 1 - Classification of nutritional status at baseline (M0) of individuals with mental disorder, Botucatu, São Paulo, Brazil, 2016
Table 2 - Metabolic profile of individuals with mental disorder at baseline (M0), Botucatu, São Paulo, Brazil, 2016

\begin{tabular}{ccc}
\hline Biochemical tests & Mean & Standard Deviation \\
\hline Total Cholesterol $(\mathrm{mg} / \mathrm{dl})$ & 193.5 & 31.5 \\
HDL cholesterol $(\mathrm{mg} / \mathrm{dl})$ & 53.9 & 11.7 \\
Blood Glucose $(\mathrm{mg} / \mathrm{dl})$ & 86.0 & 23.7 \\
Triglycerides $(\mathrm{mg} / \mathrm{dl})$ & 141.9 & 80.0 \\
\hline
\end{tabular}

Note: $\mathrm{mg} / \mathrm{dl}$ : milligrams per deciliter, HDL: High-Density Lipoprotein.

The results showed that $35.6 \%$ (16) of the patients were obese. By gender, $64.7 \%$ (11) of women and $35.7 \%$ (10) of men were overweight (overweight or obese). When checking the nutritional status according to age, adults were more obese than the elderly, $55.2 \%$ and $31.3 \%$, respectively.

Table 2 presents the results of plasma concentrations of biochemical tests that characterized the metabolic profile before the intervention (M0).

When assessing the prevalence of metabolic syndrome (MS), it was found that $31.1 \%$ (14) of patients had it, representing $35.2 \%$ (6) of women and $28.5 \%$ (8) of men. Regarding the evaluated parameters, $33.3 \%$ (15) had at least one component with alteration. Of these, $95.6 \%$ (14) presented altered WC, $66.7 \%$ (10), hypertension and $46.7 \%$ (7), altered triglyceride concentration.

Table 3 shows the mean values of BMI and increased WC at the three study moments.

The results showed that, unlike the BMI and WC values, which did not show statistical difference, the WHtR in the first 180 days responded significantly $(p<0.0001)$ to oat bran supplementation showing the positive effect of consumption on abdominal obesity.

Table 4 shows the behavior of biochemical tests, mean values and standard deviation at the four study moments ( $M 0, M 1, M 2$ and $M 3$ ).

Regarding serum cholesterol concentrations, the supplementation protocol applied was efficient to reduce its levels in the first 90 days of study $(p=0.0125)$, remaining until the end of the supplementation period and returning to the basal values after oat bran removal. As for serum HDL-cholesterol concentration, there was a statistical difference at baseline and 180 days $(p=0.0080)$. Serum triglyceride concentrations showed the most positive changes with fiber supplementation. Results were statistically lower at 3 moments $(p=0.0010)$ : baseline (M0) and 90 days (M1), 90 days (M1) and 180 days (M2) and 90 days (M1) and 180 days (M3). There was no difference in blood glucose levels during the supplementation period.

As for M3, 180 days after the last oat bran supplementation, there was a statistical difference for all parameters evaluated. Total cholesterol, glycemia and triglyceride concentrations, which showed a decrease in serum concentrations after supplementation, with the suspension of the dietary fiber supply, again increased the concentrations, with statistical significance $(0.0016,0.0004$ and $0.0004 \mathrm{p}$ value, respectively). $\mathrm{HDL}$-cholesterol concentrations in turn returned to normal (0.0155 $\mathrm{p}$ value).

Regarding the diagnosis of metabolic syndrome after 180 days of supplementation, the prevalence was $48.9 \%$ (22). 180 days after the completion of supplementation, $28.9 \%$ (13) of MS were found among the study group. This variation is due to the reduction in $\mathrm{HDL}$-cholesterol concentrations observed in $\mathrm{M} 2$ $(p=0.0080)$, and normalization in $M 3(p=0.0155)$. 
Oat bran in cardiovascular risk control in mental disorder

Table 3 - Comparison of Body Mass Index and waist circumference of individuals with mental disorders in the four study moments, Botucatu, São Paulo, Brazil, 2016

\begin{tabular}{cccccc}
\hline Anthropometry & M0 (SD) & M1(SD) & M2(SD) & M3(SD) & p value \\
\hline BMI $\left(\mathrm{kg} / \mathrm{m}^{2}\right)$ & $27.3(5.9)$ & $27.1(5.8)$ & $27.2(5.8)$ & $27.2(5.8)$ & 0.9130 \\
WC $(\mathrm{cm})$ & $98.5(15.6)$ & $96.9(15.3)$ & $95.5(15.3)$ & $95.5(15.3)$ & 0.6458 \\
WHtR & $0.61(0.11)^{\mathrm{a}}$ & $0.60(0.11)^{\mathrm{b}}$ & $0.59(0.11)^{\mathrm{c}}$ & $0.59(0.11)^{\mathrm{c}}$ & $\mathbf{p}<\mathbf{0 . 0 0 0 1}$ \\
\hline
\end{tabular}

Note: M0: baseline; M1: 90 days of supplementation; M2: 180 days of supplementation; M3: 180 days after the last supplementation; $\mathrm{kg}: \mathrm{kilogram;} \mathrm{cm}_{\mathrm{c}} \mathrm{centimeters;} \mathrm{kg} / \mathrm{m}^{2}$ : $\mathrm{kilog}$ ram per square meter, BMI: Body Mass Index; WC: Waist Circumference; WHtR: Waist-to-Height Ratio; SD: Standard Deviation, comparison obtained by ANOVA in repeated measures.

Table 4 - Comparison between the values of the components of the metabolic syndrome individuals with mental disorder in the four study moments (M0, M1, M2, M3), Botucatu, São Paulo, Brazil, 2016

\begin{tabular}{cccccc}
\hline Biochemical tests & M0 (SD) & M1(SD) & M2(SD) & M3(SD) & $\boldsymbol{p}$ value \\
\hline Total Cholesterol $(\mathrm{mg} / \mathrm{dll})^{*}$ & $193.5(31.5)^{\mathrm{a} . \mathrm{b}}$ & $173.4(31.6)^{\mathrm{c}}$ & $179.9(39.0)^{\mathrm{b} . \mathrm{c}}$ & $198.4(31.6)^{\mathrm{a}}$ & 0.0016 \\
HDL-cholesterol $(\mathrm{mg} / \mathrm{dl})^{*}$ & $53.9(11.7)^{\mathrm{a}}$ & $52.1(13.9)^{\mathrm{a} . b}$ & $45.7(12.7)^{\mathrm{b}}$ & $52.2(12.9)^{\mathrm{a} . b}$ & 0.0155 \\
Blood Glucose $(\mathrm{mg} / \mathrm{dl})^{* *}$ & $86.1(23.7)^{\mathrm{a}}$ & $80.3(44.6)^{\mathrm{a}}$ & $86.4(36.0)^{\mathrm{a}}$ & $95.5(23.8)^{\mathrm{b}}$ & 0.0004 \\
Triglycerides $(\mathrm{mg} / \mathrm{dl})^{* * *}$ & $149.9(80.0)^{\mathrm{a}}$ & $111.1(70.9)^{\mathrm{b}}$ & $137.6(100.5)^{\mathrm{a}}$ & $151.5(79.9)^{\mathrm{a}}$ & 0.0004 \\
\hline
\end{tabular}

Note: ${ }^{*} p$ value obtained from repeated measures ANOVA. Means followed by the same letter do not differ by Tukey's test at the $5 \%$ probability level. ** $p$ value obtained from the generalized linea model with gamma distribution. Means followed by the same letter differ by the Wald test at the 5\% probability level. M0: baseline, M1: 90 days of supplementation, M2: 180 days of supplementation, M3: 180 days after last supplementation, mg/dl: milligrams per deciliter, HDL: High-Density Lipoprotein, SD: Standard Deviation.

\section{DISCUSSION}

Regarding the characteristics of the population studied, most were male, the same found in the 5 studies by Melo et al $^{(24)}$ and Caluwé et $\mathrm{al}^{(25)}$. The study published by the authors Barboza e Silva ${ }^{(26)}$ highlights the higher prevalence in females, all referring to institutionalized patients. There are no consistent studies that point out and report possible gender differences ${ }^{(27)}$.

The mean age of patients evaluated in this study is lower than the study by Vargas ${ }^{(28)}$, who found a mean age of $62.7 \pm 10.4$ years in institutionalized patients and higher than $\mathrm{Garcia}^{(6)}$ and Caluwé at $\mathrm{al}^{(25)}$, evaluating non-institutionalized patients, which was $50.1 \pm$ 11.1 years. The age group $55 \pm 13$ years showed that they are young, productive age and at high risk of CVD. No studies were found in the literature discussing the age of these patients. Considering the higher risk of developing chronic diseases related to aging and metabolic disorders caused by the use of SGA, knowledge of nutritional status becomes a fundamental step in the clinical evaluation to direct care during treatment during hospitalization and outpatient care. especially lifestyle changes ${ }^{(6,25,28)}$.

Studies ${ }^{(6,25,28)}$ highlight that patients with psychotic disorders have a higher risk of obesity, especially abdominal obesity, high blood pressure, altered glycemic levels, hypertriglyceridemia, low HDL-cholesterol levels. As a consequence, metabolic syndrome, changes related to the disease itself, medication use and lifestyle are generated, especially the consumption of foods with high energy density and sedentary lifestyle. In the present study, it was found that $1 / 3$ of the MS components had increased WC, followed by low HDL-cholesterol (28.9\%). The smallest changes were observed in relation to triglyceride levels (17.8\%) and fasting glucose (6.7\%). Results that can be explained, in this case, by the use of the drug, since all patients had chronic use of antipsychotic, sedentary lifestyle and fiber consumption below the recommendations.

Most studies used the NCEP-ATP III criteria ${ }^{(29)}$ to classify MS, but the prevalence is different in both MS and altered components. Despite the changes found, when associating the components,
$11.2 \%$ of the patients had a diagnosis of MS, suggesting that the treatment of these patients should not only be about the care of the mental illness, but also the development of actions to improve it. metabolic changes and reduce the risks of CVD. The guidelines of the I Diretriz Brasileira de Diagnóstico e Tratamento de Síndrome Metabólica (freely translated as I Brazilian Metabolic Syndrome Diagnosis and Treatment Guideline) ${ }^{(30)}$ state that an eating plan for weight reduction and exercise stimulation is the first care for patients with MS. It is true that these two measures together promote weight loss, with a significant decrease in WC and visceral fat, a significant improvement in insulin resistance, consequently lower risk of developing diabetes mellitus, as well as reduced blood pressure triglycerides and increased HDL-cholesterol ${ }^{(30)}$. Guidance for increased exercise, in addition to improving metabolic health conditions, could help patients with mental disorders regarding overall well-being, improved muscle strength and even self-esteem. Study conducted with patients residing in Therapeutic Residency Service (SRT - Serviço de Residência Terapêutica), accompanied at the Psychosocial Care Center (CAPS - Centro de Atenção Psicossocial), show that the practice of physical activity encounters enough resistance, due to the number of medicines, often association of various types, these individuals have no physical disposition to even perform walking. Patients with schizophrenia, in addition to being sedentary, also use tobacco for the most part ${ }^{(31)}$, spending most of their day lying down, which makes this therapeutic option difficult to implement.

In the present study, $84.4 \%$ of patients had increased WHtR, indicating abdominal obesity. WHtR has been considered the best anthropometric index, related to hypertension and metabolic syndrome, regardless of gender, verified by studies that relate this indicator to left ventricular hypertrophy, defined by echocardiography, an important predictor of cardiac death. High body fat is related to the prevalence of CVDs mainly. Considering the conditions of the patients in the present study, this is another finding that corroborates the need for a broader view of their treatment ${ }^{(5,32)}$. 
The second option of care is the elaboration of an energyappropriate eating plan, reduction of the consumption of sugars, fats, sodium and increase of the consumption of vegetables, fruits and fibers, that is, the adoption of the dietary approach to stop Hypertension (DASH). This type of conduct is known to be difficult to follow and to maintain for a long time in patients with only MS, which can be expected in patients with psychiatric disorders. Consideration should also be given to socioeconomic conditions. When hospitalized, individuals are under the care of the institutions, most of them providing donation and campaign foods, as is the case of the present study, which does not allow wide variety in the menu. In SRTs, besides the lack of food availability, it is often the patient himself who prepares his food.

A study by Zortéa ${ }^{(33)}$, who provided nutritional counseling for overweight patients living in SRT treated at CAPS, found low adherence and resistance on the part of patients regarding the nutritional guidelines received. The expected outcome for weight loss outcome was negative.

Given all this difficulty regarding the change in dietary pattern and the inclusion of physical exercise, the purpose of this study was to supplement dietary fiber in the form of oat bran, justified by the ease of inclusion of this food (low price, without need for special preparation) on the daily menu.

The nutritional recommendation ${ }^{(15,26)}$ is that the daily fiber intake should be $20 \mathrm{~g}$ to $30 \mathrm{~g}$, preferably in the form of vegetables, legumes and whole grains, as they are also a source of various vitamins, minerals and other nutrients essential for health. Evidence showed that $50 \mathrm{~g} /$ day has a positive effect on glycemic and lipid control. There are no reports of effects on palatability and gastrointestinal symptoms ${ }^{(10)}$. There are no studies in the literature indicating the ideal amount of fiber supplementation or the time of use to improve metabolic syndrome components.

Throughout the study, there were no complaints regarding the use of supplementation. Compliance was complete and pleased the patients. The option of serving oat bran mixed with milk for breakfast did not change the hospital nutrition service routine, confirming the ease of use of this supplement in the routine.

Regarding the results of the anthropometric indicators evaluated, oat bran supplementation was effective to improve patients' WHtR, suggesting that it is a simple, low cost therapy that can be implemented in the care of patients using antipsychotics. There are no similar studies in the literature. The study time may not have been sufficient to promote weight loss. Lack of exercise and non-interference with the quality and quantity of food consumed should be considered when losing weight ${ }^{(5,32)}$. Patients throughout the study did not change their life routine.

Regarding the biochemical components of MS, although the mean values were within normal limits, in the first 90 days of supplementation (M1), they already showed significant differences in the levels of total cholesterol, triglycerides, and HDL-cholesterol, suggesting that both quantity and time were sufficient to assist in the control of these components. At the end of the study, 180 days (M2), it was found that cholesterol levels remained similar to M1 and lower than M0. Regarding HDL-cholesterol, levels decreased even more than $\mathrm{M} 0$ and $\mathrm{M} 1$, suggesting that lack of physical activity may be an important factor in maintaining these levels, since these patients are sedentary.

Triglyceride levels, which showed a significant reduction from M0 to $M 1$, increased again in $M 2$, with a statistically significant difference. A likely explanation for this variation may be the small change in diet that occurred in the last 40 days of the study. As already mentioned, the hospital scenario of this work is a philanthropic entity that depends on private donations and fundraising campaigns. In the period mentioned, there was an increase in the daily menus of carbohydrate-rich foods, especially pasta and cornmeal, and cakes in snacks, which may have influenced triglyceride results.

Despite the change in food supply, there was no increase in the prevalence of MS, allowing to conclude that oat bran supplementation was important during this period. At the end of the study, a patient who had been diagnosed with MS had an improvement in one component, a reduction in triglyceride levels. The other four showed improvement of the components, but still remained altered.

\section{Study limitations}

This study was conducted with a limited number of patients and reduced supplementation time, as it is an intervention performed for master's dissertation.

\section{Contributions to health}

Cardiovascular risks can be prevented and controlled in patients with mental disorder only by supplementing with oat bran consumed daily.

\section{CONCLUSION}

Lifestyle changes such as improved dietary patterns and increased physical activity to prevent and control changes in metabolic syndrome components and CVD risk are difficult to implement. The results of the present study showed that oat bran supplementation is an easy and viable way, both practical and financial, for the control of risk factors for the development of CVD, especially in the improvement of abdominal obesity and reduction of total cholesterol and triglyceride levels.

Further studies with larger numbers of patients, longer supplementation and different amounts of oat bran are needed to define a specific protocol for these patients.

\section{REFERENCES}

1. Joseph J, Depp C, Shih PAB, Cadenhead KS, Schmid-Schönbein G. Modified mediterranean diet for enrichment of short chain fatty acids: Potential adjunctive therapeutic to target immune and metabolic dysfunction in schizophrenia. Front Neurosci. 2017;11(MAR):1-16. Available: doi: 10.3389/fnins.2017.00155 
Oat bran in cardiovascular risk control in mental disorder

2. Hasan A, Falkai P, Wobrock T, Lieberman J, Glenthøj B, Gattaz WF, et al. World Federation of Societies of Biological Psychiatry (WFSBP) guidelines for biological treatment of schizophrenia: a short version for primary care. Int J Psychiatry Clin Pract. 2017;21(2):82-90. Available: doi: 10.1080/13651501.2017.1291839

3. Lehman AF, Lieberman J, Dixon LB, McGlashan TH, Miller AL, et al. Practice guideline for the treatment of patients with schizophrenia: second edition. Am J Psychiatry[Internet]. 2010[cited 2019 Oct 18];161(2):1--56. Available: https://psychiatryonline.org/pb/assets/raw/ sitewide/practice_guidelines/guidelines/schizophrenia.pdf

4. Elkis H, Gama C, Suplicy H, Tambascia M, Bressan R, Lyra R, et al. Consenso Brasileiro sobre antipsicótico de segunda geração e distúrbios metabólicos. Rev Bras Psiquiatr. 2008;30(1):77-85. doi: 10.1590/S1516-44462008000100014

5. Rodrigues SL, Baldo MP, Mill JG. Associação entre a razão cintura-estatura e hipertensão e síndrome metabólica: estudo de base populacional. Arq Bras Cardiol [Internet]. 2010[cited 2019 Oct 18];95(2):186-91. Available from: http://www.scielo.br/pdf/abc/v95n2/ en_aop06510.pdf

6. Garcia PCO, Moreira JC, Bissoli MC, Simões TMR. Perfil nutricional de indivíduos com transtorno mental, usuários do Serviço Residencial Terapêutico, do município de Alfenas - MG-br. Rev da Univ Val do Rio Verde[Internet]. 2013[cited 2019 Oct 18];11(1):114. Available from: http://periodicos.unincor.br/index.php/revistaunincor/article/view/909

7. Luckhoff H, Phahladira L, Scheffler F, Asmal L, Plessis S, Chiliza B, et al. Weight gain and metabolic change as predictors of symptom improvement in first-episode schizophrenia spectrum disorder patients treated over 12 months. Schizophr Res. 2019;206:171-6. doi: 10.1016/j.schres.2018.11.031

8. Cohn T, Prud'homme D, Streiner D, Kameh H, Remington G. Characterizing coronary heart disease risk in chronic schizophrenia: high prevalence of the metabolic syndrome. Can J Psychiatry. 2004;49(11):753-60. doi: 10.1177/070674370404901106

9. Nasrallah HA. Atypical antipsychotic-induced metabolic side effects: insights from receptor-binding profiles. Mol Psychiatry. 2008;13(1):2735. doi: $10.1038 /$ sj.mp.4002066

10. Faulkner G, Soundy AA, Lloyd K. Schizophrenia and weight management: a systematic review of interventions to control weight. Acta Psychiatr Scand. 2003;108(5):324-32. doi: 10.1034/j.1600-0447.2003.00218.x

11. Steemburgo T, Dall'Alba V, Gross JL, Azevedo MJ. Fatores dietéticos e síndrome metabólica. Arq Bras Endocrinol Metabol. 2007;51(9):142533. doi: $10.1590 / S 0004-27302007000900004$

12. Mello VD, Laaksonen DE. Fibras na dieta: tendências atuais e benefícios à saúde na síndrome metabólica e no diabetes melito tipo 2 . Ara Bras Endocrinol Metabol. 2009;53(5):509-18. doi: 10.1590/S0004-27302009000500004

13. Fernandes M, Paes C, Nogueira C, Souza G. Profile of antioxidant nutrient intake in patients with metabolic syndrome. Rev Ciênc Méd. 2007;16:209-19. Available from: http://periodicos.puc-campinas.edu.br/seer/index.php/cienciasmedicas/article/view/1047

14. American Dietic Association. Position of the American Dietetic Association: health implications of dietary fiber. J Am Diet Assoc. 2002,102:993-1000. doi: 10.1016/S0002-8223(02)90228-2

15. Faludi AA, Izar MCO, Saraiva JFK, Chacra APM, Bianco HT, Afiune Neto A, Bertolami A, et al. Atualização da diretriz Brasileira de Dislipidemia e Prevenção da Aterosclerose. Arq Bras Cardiol 2017; 109(25Supl.1):1-75. doi: 10.5935/abc.20170121

16. Rocha CLL, Donatto F, Liberali R, Navarro F, Souza TPJ, Prestes J. Efeitos do farelo de aveia sobre parâmetros antropométricos e bioquímicos em corredores de rua. Rev Educ Física UEM. 2012;23(1):115-122. doi: 10.4025/reveducfis.v23i1.10557

17. Wolever TMS, Jenkins AL, Prudence K, Johnson J, Duss R, Chu Y, et al. Effect of adding oat bran to instant oatmeal on glycaemic response in humans-a study to establish the minimum effective dose of oat $\beta$-glucan. Food Funct. 2018;9(3):1692-700. doi: 10.1039/c7fo01768e

18. Mira GS, Graf H, Cândido LMB. Visão retrospectiva em fibras alimentares em ênfase em beta-glucanas no tratamento do diabetes. Braz J Pharmaceut Sci. 2009;45(1):11-20. doi: 10.1590/S1984-82502009000100003

19. Bernaud FSR, Rodrigues TC. Fibra alimentar: ingestão adequada e efeitos sobre a saúde do metabolismo. Arq Bras Endocrinol Metab. 2013;57(6):397-407. doi: 10.1590/S0004-27302013000600001

20. World Health Organization (WHO). Physical status: the use and interpretation of anthropometry. Report of a WHO Expert Committee [Internet]. WHO Technical Report Series 854. Geneva; 1998[cited 2019 Oct 18]. Available in: https://www.who.int/childgrowth/publications/ physical_status/en/

21. Nutrition Screening Initiative. Nutrition interventions manual for professionals caring for older Americans. Washington, DC: NutritionScreening Initiative, 1992.

22. Ashwell M, Hsieh SD. Six reasons why the waist-to-height ratio is a rapid and effective global indicator for health risks of obesity and how its use could simplify the international public health message on obesity. Int J Food Sci Nutr. 2005;56(5):303-7. doi: 10.1080/09637480500195066

23. Alberti KGMM, Eckel RH, Grundy SM, Zimmet PZ, Cleeman Jl, Donato KA, et al. Harmonizing the metabolic syndrome: A joint interim statement of the international diabetes federation task force on epidemiology and prevention; National heart, lung, and blood institute; American heart association; World heart federation; International. Circulation. 2009;120(16):1640-5. doi: 10.1161/ CIRCULATIONAHA.109.192644

24. Melo MCA, Albuquerque SGC, Luz JHS, Quental PTLF, Sampaio AM, Lima AB. Perfil clínico e psicossocial dos moradores em hospitais psiquiátricos no Estado do Ceará, Brasil. Ciênc Saúde Coletiva. 2015;20(2):343-52. doi: 10.1590/1413-81232015202.2062013 
25. Caluwé L, van Buitenen N, Gelan PJ, Crunelle CL, Thomas R, Casseres S, et al. Prevalence of metabolic syndrome and its associated risk factors in an African-Caribbean population with severe mental illness. Psychiatry Res. 2019;281(April):112558. Available from: doi: 10.1016/j. psychres.2019.112558

26. Barboza PS, Silva DA. Medicamentos antidepressivos e antipsicóticos prescritos no centro de atenção psicossocial (CAPS) do município de Porciuncula-RJ. Acta Bioméd Bras [Internet]. 2012[cited 2019 Oct 18];3(1):85-97. Available from: http://www.actabiomedica.com.br/index. php/acta/article/view/39

27. Leitão CL, Guimarães LR, Lobato MI, Belmonte-de-Abreu P. Ganho de peso e alterações metabólicas em esquizofrenia. Rev Psiq Clin. 2007;34:184-8. doi: 10.1590/S0101-60832007000800007

28. Freitas PHB, Granjeiro PA, Vecchia BP, Paula ML, Tavares MC, Machado RM. Prevalência de síndrome metabólica em pacientes com esquizofrenia refratária. Cienc Enferm [Internet]. 2016[cited 2019 Oct 18];22(3):11-24. Available from: https://pesquisa.bvsalud.org/portal/ resource/pt/biblio-839752

29. Cleeman J. Executive summary of the third report of the National Cholesterol Education Program (NCEP) expert panel on detection, evaluation, and treatment of high blood cholesterol in adults (adult treatment panel III). J Am Med Assoc. 2001;285(19):2486-97. doi: 10.1001/jama.285.19.2486

30. Sociedade Brasileira de Cardiologia. Diagnóstico e tratamento. Arq Bras Cardiol [Internet]. 2005;84:1-27. Available from: http://pesquisa. bvsalud.org/bvsms/resource/pt/mis-23299

31. Aguilar E, Coronas R, Caixàs A. Síndrome metabólico en pacientes esquizofrénicos con tratamiento antipsicótico. Med Clin (Barc). 2012;139(12):542-6. https://doi.org/10.1016/j.medcli.2012.05.028

32. Lavie CJ, Milani R V, Ventura HO. Obesity and Cardiovascular Disease. Risk Factor, Paradox, and Impact of Weight Loss. J Am Coll Cardiol. 2009;53(21):1925-32. Available from: doi: 10.1016/j.jacc.2008.12.068

33. Zortéa K, Guimarães LR, Gama CS, Belmonte-de-Abreu PS. Estado nutricional de pacientes com esquizofrenia frequentadores do Centro de Atenção Psicossocial (CAPS) do Hospital de Clínicas de Porto Alegre. J Bras Psiquiatr. 2010;59(2):126-30. doi: 10.1590/ S0047-20852010000200008 